\title{
TINJAUAN MANAJEMEN PENCEGAHAN DAN PENGENDALIAN COVID-19 DI BIDANG INDUSTRI PENERBANGAN
}

\author{
Febie Karmani Putra ${ }^{1}$, Robiana Modjo $^{2}$, Fatma Lestari ${ }^{3}$ \\ Departemen Keselamtan dan Kesehatan Kerja, Fakultas Kesehatan Masyarakat, Universitas Indonesia \\ kampus baru UI Depok, Jawa Barat 1645 Indonesia \\ bian@ui.ac.id, febie.karmani91@ui.ac.id
}

\begin{abstract}
CoronaVirus Disease 19 (COVID-19) has a wide impact on all industries. Aviation is the most impactful industry. PT X as the oldest Air Operator Certificate company in Indonesia must run its business during this pandemic. The company is trying to implement COVID-19 Prevention and Control to stay afloat. This study provides an overview of the implementation and recommendations of effective COVID-19 prevention and control management strategies. The research design is a cross sectional study using online interviews and Focus Group Discussion (FGD). The research was conducted at Jakarta using an online meeting application in February 2021. The data will be analysed using Mix Ground Theory and SWOT Analysis methods. Barrier Factors and Challenges such as Maintaining Health Protocols in the area/base of work locations, Potential Risks in the largest area, limited resources, limited flight operations, Drivers Factors such as a commitment to occupational safety and health and business continuity. The resulting Impacts, such as low demand for the needs of the aviation industry, changes in the online working and additional costs for COVID19 tests in flight operations. The implementation of the COVID-19 health protocol at PT X is generally good. PT X experienced a significant impact on operations like other airlines in general.
\end{abstract}

Keywords : : Management Prevention, COVID-19, Aviation Industry, SWOT Analysis, Ground Theory

\begin{abstract}
ABSTRAK
Corona Virus Disease 19 (COVID-19) berdampak luas pada semua industri. Penerbangan menjadi industri yang paling berdampak. PT X sebagai Perusahaan Sertifikat Operator Udara tertua di Indonesia harus menjalankan usahanya di masa pandemi ini. Perusahaan ini berupaya menerapkan Pencegahan dan Pengendalian COVID-19 untuk tetap bertahan. Kajian ini memberikan gambaran implementasi dan rekomendasi, strategi manajemen pencegahan dan pengendalian COVID-19 yang efektif. Desain penelitian adalah cross sectional study dengan menggunakan wawancara secara daring dan Focus Group Discussion (FGD). Penelitian dilakukan di Jakarta dengan menggunakan aplikasi online meeting pada bulan Februari 2021. Data akan dianalisis menggunakan metode Mix Ground Theory dan Analisis SWOT. Faktor Penghalang dan Tantangan seperti menjaga protokol kesehatan di daerah lokasi kerja, potensi risiko di daerah yang terbesar, sumber daya yang terbatas, terbatasnya operasionalnya penerbangan, kemudian Faktor Pendorong seperti adanya komitmen keselamatan dan kesehatan kerja serta keberlangsungan bisnis. Untuk Dampak yang dihasilkan, seperti rendahnya permintaan akan kebutuhan industri penerbangan, perubahan lingkungan kerja secara daring dan adanya tambahan biaya (additional cost) untuk tes COVID-19 didalam operasional penerbangan. Implementasi protokol kesehatan COVID-19 pada PT X secara umum sudah baik. PT X mengalami dampak yang cukup signifikan di operasional seperti pada umumnya perusahaan penerbangan lainnya.
\end{abstract}

Kata Kunci : Manajemen Pencegahan, COVID-19, Industri Penerbangan, Analisis SWOT, Teori Ground 


\section{PENDAHULUAN}

Pandemi COVID-19 masih terus berlangsung sejak akhir 2019. Laporan menunjukkan lebih dari 2,7 juta kasus baru dilaporkan setiap minggu di seluruh dunia. Secara global, sekitar separuh negara mengalami penurunan kasus, sementara separuh lainnya mengalami peningkatan kasus baru. Pandemi ini dapat mengakibatkan $290.000 \quad-\quad 650.000$ kematian setiap tahun. Pada tahun 2020, ada sekitar 1,8 juta kematian COVID-19 (World Health Organization, 2020).

Di Indonesia keadaan COVID-19 tidak lebih baik, berdasarkan laporan Kementerian Kesehatan, 1 minggu terakhir terjadi kenaikan kasus sebesar $7.3 \%$ yang terdapat di 17 Provinsi yang mengalami kenaikan kasus. Pada provinsi yang mengalami kenaikan, peningkatan tertinggi terlihat di Jawa Barat yang naik 39,9\%, diikuti DKI Jakarta yang naik 3,9\%, Jawa Tengah naik $7,3 \%$, Sulawesi Tengah naik 133,4\%), dan Sulawesi Selatan naik 8,8\% (Kemenkes, 2020). Sementara itu kegiatan vaksinasi masih terus dilakukan untuk menurunkan angka kematian dari COVID19. Salah satu akibat yang ditimbulkan oleh COVID-19 selain dengan adanya kematian dan kesakitan, yaitu pada Bidang Ekonomi.

Perlambatan pertumbuhan ekonomi akan mempengaruhi perusahaan kecil dan menengah dalam mempertahankan keberlangsungan bisnisnya. Sektor jasa, termasuk penerbangan, perjalanan, dan pariwisata, terkena dampak paling parah (Dekker, 2020). Maskapai penerbangan telah mengalami penurunan tajam dalam lalu lintas di rute internasional dan nasional. Pandemi COVID-19 mendorong perubahan yang menyebabkan "Dampak dan Ketidakpastian Besar" dalam sektor penerbangan (Mhalla, 2020).

Upaya untuk mengendalikan penyebaran COVID-19, pembatalan penerbangan dan larangan perjalanan mempengaruhi kondisi operasional maskapai penerbangan. Dampak COVID19 pada bidang penerbangan seperti pengurangan jam kerja pada kru penerbangan, pengurangan upah, Pengurangan upah secara sepihak, cuti berbayar dan tidak berbayar, pembekuan perekrutan pegawai serta, adanya Putus Hak Kerja (ICAO,2020). Untuk mengatasi hal tersebut, pemerintah perlu melakukan tindakan keberlanjutan penanganan untuk menangani hal tersebut.

Melalui Keputusan Menteri Kesehatan Republik Indonesia No. HK.01.07/Menkes/328/2020 tentang Pedoman Pencegahan dan Pengendalian Penyakit Coronavirus Disease 2019 (COVID-19) di Kantor dan Tempat Kerja Industri dalam Mendukung Keberlanjutan Usaha dalam Situasi Pandemi. Perlu dilakukan sejauh mana implementasi dari kebijakan yang berkaitan dengan Pedoman tersebut di dalam industri penerbangan.

Penelitian ini dievaluasi penerapan Protokol Kesehatan Normal Baru di industri penerbangan. Untuk mencapai tujuan tersebut, pertanyaan penelitian seperti bagaimana deteksi dan pengujian cepat infeksi COVID-19 diterapkan di industri, pelaksanaan surveilans kesehatan terhadap infeksi COVID-19 di industri, sistem pelacakan infeksi COVID-19 diterapkan, factor hambatan penerapan Protokol Kesehatan COVID-19 di industri, faktor pendorong penerapan Protokol Kesehatan COVID-19 di industri, dampak penerapan Protokol Kesehatan COVID-19 di industry, Peraturan Pemerintah dan Industri tambahan yang memandu Protokol Kesehatan COVID-19 di industri, Protokol Kesehatan COVID-19 berdampak pada produktivitas (baik di rumah maupun di tempat kerja), serta penerapan Protokol Kesehatan COVID-19 di industri sejalan dengan pedoman Pemerintah.

\section{METODE}

Desain penelitian ini adalah studi cross-sectional, dengan metode mix Ground Theory dan Strengths, Weakness, Opportunities, serta Threats (SWOT) Analisis. Ground Theory merupakan 
seperangkat prosedur yang digunakan untuk menyusun sebuah teori yang menjelaskan sebuah proses mengenai sebuah topik substantif (Walker, 2006). Sedangkan Analisis SWOT merupakan salah satu metode untuk menggambarkan kondisi dan mengevaluasi suatu masalah, proyek atau konsep bisnis yang berdasarkan faktor eksternal dan faktor internal yaitu strength, opportunities, weaknesses, threats. (Sarsby, 2016).

Penelitian ini dilakukan untuk memberikan gambaran penerapan Protokol Kesehatan COVID-19 di PT X sebagai industri penerbangan. Anggota Tim Satgas COVID-19 yang diwawancara (Perwakilan Manajemen, HR Department, Safety and Security Department serta General Affair Department).

Penelitian ini merupakan kelanjutan dari penelitian (Cook, 2020) tentang evaluasi mengenai penerapan protokol kesehatan di era normal baru. Pengukuran dilakukan dengan cara pengkodean pada tabel 1.

Tabel 1. Pengkodean Tindakan Pencegahan COVID-19

\begin{tabular}{cc}
\hline Kode & Pengukuran \\
\hline N1 & Tim Satgas COVID-19 \\
\hline N2 & $\begin{array}{c}\text { 3M (Masker, Mencuci Tangan dan } \\
\text { Menjauhi Kerumunan) }\end{array}$ \\
\hline N3 & 3T (Testing, Tracing dan Treatment) \\
\hline N4 & Work From Home (WFH) \\
\hline N5 & Rapid Test - Acak \\
\hline N6 & Rapid Test - Tinggi Risiko \\
\hline N7 & Rapid Test - Semua \\
\hline N8 & PCR Test \\
\hline N9 & Cek Temperatur \\
\hline N10 & Penilaian Risiko Individu \\
\hline N11 & Dokter/Klinik Dokter \\
\hline N12 & Sistem Roasting \\
\hline N13 & Komikasi Internal \\
\hline
\end{tabular}

\begin{tabular}{lc}
\hline N14 & Edukasi \\
\hline N15 & Pemantauan Pegawai dan Penegakan \\
\hline N16 & Manajemen Kembali Bekerja \\
\hline N17 & Pemberian Suplemen
\end{tabular}

Penelitian ini memperoleh persetujuan etik dari Komisi Etik Penelitian dan Pengabdian Masyarakat Fakultas Kesehatan Masyarakat, Universitas Indonesia No. 436/UN2.F10.D11/PPM.00.02/2020 pada tanggal 11 Juli 2020 dan dari Human Research Ethics University of Queensland (20001712) pada tanggal 21 Juli 2020.

Anggota Tim Satuan Gugus Tugas COVID-19 PT $\mathrm{X}$ berpartisipasi lewat wawancara daring (online) menggunakan platform Zoom. Data sekunder, seperti kebijakan dan prosedur COVID-19, contoh contact tracing, dokumentasi pengecekan Swab Antigen/PCR test, Dokumentasi Pembersihan Gedung/Kantor, Dokumentasi Pembersihan Pesawat, Laporan Bulanan Tim Gugus Tugas.Transkrip wawancara diringkas dan dianalisis secara tematis menggunakan metode Mix Ground Theory dan SWOT Analysis.

\section{HASIL}

\section{Gambaran Perusahaan Penerbangan}

Berdasarkan Profil PT X, didirikan pada Februari 1969. Perusahaan layanan utilitas helikopter pertama di Indonesia, yang melayani industri seperti industri minyak gas, transportasi personnel, survei geologi, konstruksi pipa, eksplorasi minyak, dan transportasi medis. Industri Batu Bara melayani survey geologi, transportasi medis serta pengangkutan barang internal. Industri Perkebunan seperti Heli logging, Transportasi Medis dan Personel dan Pemadaman Api. Saat ini PT $\mathrm{X}$ memiliki 113 karyawan diantaranya Personel Penerbangan (pilot, engineer, load master) dan Bukan Personel Penerbangan. Tipe armada yang dioperasikan seperti Bell 412, EP, Bell 412 SP, Bell 505, 
AgustaWestland 119 serta Airbus Eurocopter (EC) 130 B4. Saat ini, perusahaan ini melakukan layanan Patroli Kebakaran Hutan, Bantuan Bencana pada wilayah Sumatera (Palembang, Jambi, Riau serta Kalimantan Barat) serta Papua. Total Jam Penerbangan (Flight Hours) yang dicatat pada tahun 2020 sejumlah 3308 Jam dan Jam Kerja (Man Hour) yang dilaporkan tercatat yaitu 307.864 Jam.

Dengan menggunakan Teori Ground, Ada beberapa proses tindakan untuk mengatur Penyebaran COVID-19 di tempat kerja perusahaan ini, seperti:

\section{Test Antigen Bulanan}

Kegiatan ini dilakukan setiap awal bulan atau setelah adanya libur panjang. Hal ini dilakukan untuk meminimalkan risiko penyebaran yang terjadi di dalam kantor untuk seluruh karyawan yang bekerja di kantor (WFO). Kegiatan ini dilakukan selama 2 hari untuk mencakup seluruh karyawan.

"Setiap bulan, kantor kita selalu mengadakan tes antigen baik secara mandiri maupun dengan klinik rekanan" (N7)

"Tes Antigen juga dilakukan ketika sehabis cuti atau ada tanggal merah dengan status long-weekend" (N6)

\section{Prosedur 3M di Tempat Kerja}

Prosedur 3M (Memakai masker, Mencuci tangan pakai sabun dan air mengalir serta Menjaga jarak) merupakan prosedur yang telah disebutkan didalam Peraturan Kementerian Kesehatan HK.01.07/MENKES/328/2020. PT X telah mengimplementasi peraturan Kementerian Kesehatan tersebut, tertuang dalam internal memo perusahaan yang diterbitkan melalui Interoffice memo No: 06-009.NUH.III.20 Protokol Kewaspadaan Pencegahan Coronavirus Disease (COVID-19), 06011.NUH.III.20 Protokol Kerja Pencegahan
Coronavirus Disease (COVID-19), 06012.NUH.III.20 Protokol Pelaksanaan Monthly Safety Meeting Selama Masa Pandemi COVID-19, 06-14.NUH.VI.20 Protokol Kerja Pencegahan COVID-19 selama Fase PSSB Transisi dan 0617.NUH.VI.20 Operasional Transportasi Udara Pada Masa Pandemi COVID-19.

"Kita sudah membuat peraturan yang terkait dengan regulasi kemenkes terutama tentang 3M. Peraturan tersebut dituangkan dalam Interoffice Memo Perusahaan" (N2)

"Peraturan ini berlaku untuk operasional gedung serta pesawat” (N2)

\section{Pengukuran Suhu}

Kegiatan pengukuran suhu juga dilakukan oleh PT $X$ pada setiap karyawan/tamu yang akan berkunjung ke PT X. Pengukuran suhu dilakukan secara manual kepada seluruh karyawan. Bagi karyawan yang mempunyai suhu diatas $37,5^{\circ}$ Celsius, karyawan atau tamu tersebut tidak diperbolehkan untuk memasuki kantor.

"Pengukuran suhu dilakukan sebelum memasuki gedung kantor juga memasuki pesawat" (N9)

\section{Peraturan Bekerja dari Rumah (Work From Home) dan Work From Office (WFO)}

Kebijakan tentang Komposisi WFH (Work From Home) dan Work From Office (WFO) tersebut didasarkan pada beberapa kriteria, yaitu: Usia, Jabatan serta Keperluan Kantor. Komposisi rentang umur yang bekerja di PT X berusia sekitar 25 - 65 tahun. Kebijakan diawali dengan komposisi 50\% WFO dan 50\% WFH dan/atau sesuai kebijakan pemerintah daerah berdasarkan status pandemi. Penentuan juga didasarkan berdasarkan keputusan manajer yang bertanggung jawab pada setiap divisi departemen masingmasing. 
"WFH dan WFO juga diterapkan untuk karyawan bukan kru penerbang. Komposisinya sesuai dengan peraturan yang berlaku. Untuk Kru penerbang, tidak ada peraturan ini”. (N4)

\section{Sistem Pelacakan Kontak Digital COVID-19 (Contact Tracing Digital System)}

PT X bersama dengan Pihak Ketiga memberlakukan Sistem Pelacakan Kontak Digital COVID-19 (Contact Tracing Digital System). Sistem ini mengharuskan setiap karyawan/tamu yang masuk kedalam kantor untuk melakukan scanning barcode yang tersedia di setiap ruangan. Guna barcode ini untuk mendeteksi/mencatat siapa saja yang berada pada ruangan tersebut, sehingga mudah dilakukan contact tracing apabila ditemukan kasus terkonfirmasi positif. Sistem ini juga melakukan surveillance tentang keadaan karyawan yang dilakukan setiap hari melalui pengisian kuesioner yang dikirimkan via email.

Sistem ini juga diberlakukan pada seluruh lokasi PT $\mathrm{X}$ termasuk setiap pesawat. Bagi penumpang maupun kru penerbang yang akan melakukan penerbangan, diwajibkan melakukan scanning pada barcode yang tertempel pada sisi kanan dan kiri pintu pesawat. Hal ini berlaku untuk penumpang maupun kru penerbang pada sebelum penerbangan (preflight) serta setelah penerbangan (postflight).

"Kami bekerja sama dengan penyedia sistem tracing untuk melakukan fungsi contact-tracing juga melakukan selfassessment untuk setiap karyawan" (N3)

"Sistem ini membantu dalam melakukan pemetaan penyebaran COVID19 di lingkungan kerja kami". (N3)

\section{Pembentukan Tim Penanggulangan COVID-19 di Tempat Kerja}

Berdasarkan SK 06-16.NUH.V.20 tentang Penunjukan Tim Penanggulangan COVID-10 di Tempat Kerja, PT X telah menunjuk Tim Satuan Tugas (Satgas) Penanggulangan COVID di Tempat Kerja. Tim tersebut terdiri dari Safety and Security Department, Human Resource Department, General Affair Department. Tim tersebut bertugas sesuai dengan Peraturan Kementerian Kesehatan HK.01.07/MENKES/328/2020 untuk melakukan Pencegahan berupa menerapkan dan pemantauan implementasi protokol COVID-19 di tempat kerja, serta penanganan jika terjadi kasus positif yang terjadi di dalam perkantoran, yang terdiri dari contact tracing, disinfeksi hingga pemantauan orang terkonfirmasi mulai dari awal perawatan hingga kembali bekerja. Tim Satgas juga bekerja sama dengan salah satu klinik untuk penyediaan dokter dan tenaga medis untuk keperluan terkait Penanganan COVID-19 di Tempat Kerja. Tim Satgas COVID-19 dipimpin oleh Safety and Security Manager.

"Kami membentuk Tim Satgas melalui SK Direktur Utama. Tim ini kolaborasi 3 departemen yang ada di kantor pusat" (N1)

\section{Promosi dan Edukasi COVID-19}

Kegiatan yang secara rutin dilakukan oleh Tim Satgas COVID-19 juga dilakukan Sosialisasi terkait COVID-19. Kegiatan ini secara rutin dilakukan oleh PT X dalam mengedukasi karyawan untuk memberikan informasi yang valid dan menghindari hoaks yang sering beredar didalam masyarakat. Kegiatan ini berupa sesi tanya jawab setelah agenda monthly safety meeting terkait COVID-19 serta memberikan Bulletin terkait COVID-19 yang disebar melalui email pribadi seluruh karyawan.

"Salah satu kegiatan Satgas kami, yaitu memberantas hokas informasi COVID-19 
untuk karyawan kami. Kami melakukannya setelah dilakukannya Safety Meeting Bulanan" (N14)

\section{Program Desinfeksi}

Program ini terbagi menjadi 2 prosedur. Untuk penanganan desinfeksi gedung pusat, program harian dilakukan pembersihan setiap 4 jam sekali yang dilakukan oleh Office Boy pada tempattempat yang paling sering disentuh oleh karyawan, seperti gagang pintu, tempat fotokopi, ruang meeting, meja, pantry dan lain-lain. Program mingguan, dilakukan pada setiap hari Sabtu atau hari libur dengan pembersihan menyeluruh kepada seluruh ruangan. Pembersihan ini menggunakan desinfeksi cair serta penggunaan Sinar Ultra Violet (UV).

Untuk di pesawat, program pembersihan dilakukan pada setiap penerbangan. Pembersihan dilakukan pada awal penerbangan (pre-flight) serta selesai penerbengan (post-flight). Pembersihan menggunakan carian yang aman digunakan pada permukaan pesawat. Bagian-bagian yang dilakukan pembersihan pada bagian pesawat pada covers, lantai, panelling, jendela, internal and external handle, pengait sabuk pengaman, tempat duduk dan pelindung tempat duduk, stretchers (jika terdapat didalam pesawat), handle pintu (dalam dan luar), kompartemen kargo, ear protector, emergency life raft (offshore operation) dan life vest (pelampung-offshore operation). Kegiatan ini juga didokumentasikan dengan menggunakan formulir daftar periksa sebagai bahan evaluasi. Kegiatan ini dilakukan oleh personel penerbangan dengan menggunakan Alat Pelindung Diri (APD) sesuai dengan Surat Edaran Kementerian Perhubungan 13 Tahun 2020 Operasional Transportasi Udara Dalam Masa Kegiatan Masyarakat Produktif dan Aman dari Coronavirus Disease 2019.

"Pembersihan kantor kita lakukan harian dan mingguan untuk di kantor utama sedangkan untuk di pesawat kami lakukan setiap hari jika ada penerbangan. Untuk pembersihan di pesawat sesuai dengan instruksi dari kementerian Perhubungan". (N3)

\section{Pembatasan Perjalanan Dinas}

Secara umum PT $\mathrm{X}$ telah memberlakukan pembatasan tersebut untuk seluruh karyawan dalam bepergian. Namun untuk kebutuhan pergantian kru (crew change) tetap harus dilakukan. Berdasarkan Civil Aviation Safety Regulation (CASR) 135 Republik Indonesia tentang Certification and Operating Requirements: For Commuter and Charter Certificate Holders, seorang pilot mempunyai batas "duty time" saat bertugas, sehingga diharuskan untuk berganti dan melakukan perjalanan dinas.

"Untuk karyawan bukan kru penerbang, pembatasan perjalanan dinas dilakukan. Namun untuk kru penerbang tidak diberlakukan". (N12)

\section{Peraturan Terkait Pengaturan Operasi Penerbangan}

Sesuai dengan Surat Edaran Kementerian Perhubungan 13 Tahun 2020 tentang Operasional Transportasi Udara Dalam Masa Kegiatan Masyarakat Produktif dan Aman Dari Coronavirus Disease 2019, Jumlah yang diperbolehkan untuk mengangkut penumpang sejumlah $70 \%$ dari kapasitas pesawat. Sehingga di dalam pesawat tidak terjadi kepadatan dan tersedia tempat isolasi saat terbang, Sebelum melakukan penerbangan, setiap penumpang diwajibkan menunjukan surat bebas COVID-19 berupa Surat Swab Antigen dan/atau Swab PCR. Setiap penumpang yang akan melakukan penerbangan akan dilakukan pengecekan suhu, pengisian kuesioner (menggunakan sistem surveillance barcode) kemudian setiap penumpang diwajibkan menggunakan masker. PT X berkomitmen, apabila ada penumpang yang menunjukan 
gejala COVID-19, maka PT X tidak akan mengizinkan penumpang tersebut untuk terbang.

PT $X$ juga menyediakan Universal Precaution Kit (UPK) pada setiap pesawat. UPK yang terdiri dari serbuk kering yang dapat mengubah tumpahan cairan kecil menjadi gel steril (dry powder that can convert small liquid spill into a sterile granulated gel), desinfektan untuk membersihkan permukaan (germicidal disinfectant for surface cleaning), tisu disinfektan (skin wipes), masker wajah/pelindung mata (terpisah atau kombinasi) (faceleye mask (separate or combined)), pelindung wajah transparan (faceshield), sarung tangan sekali pakai (disposable gloves), kain atau celemek pelindung (protective apron), handuk besar yang memiliki daya serap (large absorbent towel), sendok pengeruk (pick-up scoop with scraper), kantong pembuangan limbah (biohazard disposal waste bag) dan kertas instruksi penggunaan alat perlindungan pribadi (personal protection equipment /ppe) yang terdiri dari pelindung wajah (face shield), sarung tangan (gloves), celemek berlengan panjang (long sleeves apron) dan bahan pembersih tangan (hand sanitizer).

"Kegiatan operasi penerbangan sesuai dengan instruksi kementerian perhubungan, diantaranya prosedur membawa penumpang seperti menunjukan hasil swab, memakai masker dsb. Untuk perlengkapan juga kami siapkan untuk disetiap pesawat yaitu Perlengkapan UPK”. (N2)

\section{Kuesioner Penilaian Diri (Self- Assessment)}

Penilaian terhadap kondisi diri sendiri juga dilakukan PT $\mathrm{X}$ dalam melakukan pencegahan dan penanganan COVID-19 di tempat kerja. Kegiatan dini dilakukan menggunakan pengisian secara daring (online) yang dikirimkan kepada masingmasing email karyawan pada setiap hari pukul 18.00 waktu setempat. Kuesioner ini wajib diisi oleh karyawan setiap hari sebelum bekerja pada keesokan harinya (baik WFO/WFH).

Penumpang yang akan melakukan penerbangan juga diwajibkan mengisi kuesioner tersebut dengan cara menggunakan scanning barcode sebelum melakukan penerbangan.

"Sejalan dengan adanya kerjasama dengan pihak ketiga terkait contact tracing, pemberian kuesioner harian bagi seluruh karyawan juga diberikan melalui email" (N10)

\section{Pemberian Vitamin kepada Karyawan}

Sebagai bentuk komitmen, PT X juga melakukan pemberian vitamin kepada seluruh karyawan yang ada baik dengn pemberian suplemen oral maupun injeksi. Kegiatan ini dilakukan setiap 3 bulan sekali kepada seluruh karyawan.

"Kami juga memberikan vitamin berupa vitamin kunyah dan suntikan vitamin $C$. Pemberian ini dilakukan setiap 3 bulan sekali atau sesuai permintaan manajemen" (N17)

\section{Program Vaksinasi COVID-19}

PT X berupaya memberikan vaksinasi kepada seluruh karyawan dengan vaksin yang tersedia oleh pemerintah. Melalui Indonesia National Air Carrier Association (INACA), PT X akan melakukan kegiatan vaksinasi bersama dengan perusahaan penerbangan lainnya yang dilakukan secara bertahap kepada seluruh karyawan. Vaksinasi ini berlkau baik untuk kru penerbang maupun bukan kru penerbang.

"Saat ini kami sedang mengusahakan program vaksinasi melalui INACA, namun juga kami mengusahakan via Program Vaksinasi Gotong-Royong dari pemerintah. Manajemen berkomitmen memberikan vaksin kepada seluruh karyawan”. (N17) 
Analisa SWOT, yang didapatkan seperti pada berikut ini.

\section{Faktor Penghalang dan Tantangan}

Menjaga Protokol Kesehatan kepada seluruh karyawan selama bekerja, terutama di base/site merupakan faktor tantangan yang dihadapi PT $\mathrm{X}$ dalam mengimplementasikan Protokol COVID-19 di Tempat Kerja. PT X mempunyai banyak base yang tersebar di wilayah Indonesia, sehingga minimnya pengawasan dalam penerapan yang diungkapkan oleh Safety and Security Manager.

"Banyaknya site di seluruh Indonesia dan terbatasnya kerja, pemantauan penegakan Protokol COVID-19 menjadi hal yang sulit dicapai kemudian ketaatan kru di lapangan kadang sulit ditegakan, karena tidak ada yang mengawasi, apalagi ketika beroperasi di luar bandara"

Potensi Risiko Infeksi terutama terjadi di base lokasi. Minimnya Petugas yang memantau protokol COVID-19 ditempat kerja serta kurangnya pengetahuan tentang Protokol COVID-19 didaerah membuat pekerja/karyawan menjadi tidak terpantau dalam pelaksanaan protokol COVID-19 yang diungkapkan oleh Safety and Security Manager.

"Pelaksanaan Protokol COVID-19 untuk di base operasi yang berada di daerah terpencil juga di diperberat dengan daerah tersebut yang minimnya edukasi tentang pandemi COVID-19. Kemudian Ketika beroperasi di luar bandar udara, karena kami helikopter, dan kru memasuki daerah terpencil, terkadang kru lalai dalam menerapkan protokol kesehatan dikarenakan berada didaerah yang tidak patuh protokol kesehatan".

Sumber daya yang tidak mencukupi terutama masalah keuangan terkait program pencegahan juga menjadi fokus perhatian terkait pelaksanaan program pencegahan dan kontrol COVID-19 yang diungkapkan oleh Human Resource Manager.

"Saat ini, perusahaan dituntut mengeluarkan dana lebih dalam manajemen COVID-19 dan dilain pihak dunia industri penerbangan secara umum sedang mengalami penurunan permintaan".

Persyaratan penerbangan yang begitu banyak ditambah lesunya terkait permintaan dan kebutuhan penerbangan, membuat beberapa kru penerbang menjadi bingung terkait regulasi yang terbaru dalam operasi penerbangan yang diungkapkan oleh Safety and Security Manager.

"Peraturan yang berubah-ubah juga membuat kru dilapangan menjadi bingung terkait protokol COVID-19"

\section{Faktor Pendorong}

Salah satu faktor pendorong dalam implementasi protokol COVID-19 di tempat kerja yaitu mencegah dan melindungi karyawan dari Penularan COVID-19. PT X setuju bahwa perusahaan sebagai pemberi kerja menyatakan bahwa perusahaan harus memberikan perlindungan selama pandemi. Perusahaan memastikan bahwa pekerja saat bekerja terlindungi dari paparan virus Safety and Security Manager.

"Sesuai mandat Kebijakan Keselamatan Perusahaan, Perusahaan wajib melindungi pekerja selama bekerja, karena karyawan merupakan aset yang harus dijaga".

\section{Dampak}

Seperti pada bagian sebelumnya, dampak signifikan yang terjadi dalam implementasi ini yaitu dalam hal bisnis, terutama rendahnya permintaan akan kebutuhan industri penerbangan seperti yang disampaikan General Affair Manager. 
"Kita saat ini sedang bertahan dan berjuang dalam dunia industri, PSBB membuat orang terbatas dalam bepergian dan berdampak pada needs and demand dari jasa penerbangan, kemudian Income yang menjadi sedikit ditambah banyaknya penerbangan serta biaya penanganan covid-19 menjadi hal yang berat"

Adaya perubahan lingkungan kerja secara daring seperti kegiatan komunikasi rutin menggunakan teknologi digital seperti yang disampaikan General Affair Manager.

"Pekerja diwajibkan menggunakan teknologi dalam bekerja seperti akses online meeting, data sharing, dll".

Dampak yang juga terasa seperti adanya tambahan biaya (additional cost) untuk tes COVID-19 perihal perjalanan bisnis dan manajemen pencegahan dan kontrol COVID-19 di tempat kerja seperti yang disampaikan Human Resource Manager.

"Perusahaan juga mengeluarkan biaya tambahan untuk swab pcr test dan swab antigen test rutin sebagai kompensasi keberlangsungan usaha di tengah pandemi seperti tes COVID-19”.

\section{Ringkasan Tindakan Pencegahan COVID-19}

Berikut tabel. 2 merangkum langkah-langkah utama yang dilaporkan organisasi dalam menangani pandemi COVID-19.

Tabel 2. Ringkasan Tindakan Pencegahan COVID-19 PT X

\begin{tabular}{ccc}
\hline Kode & Pengukuran & PT X \\
\hline N1 & Tim Satgas COVID-19 & Ada \\
\hline N2 & $\begin{array}{c}\text { 3M (Masker, Mencuci } \\
\text { Tangan dan Menjauhi } \\
\text { Kerumunan) }\end{array}$ & Ada \\
\hline N3 & 3T (Testing, Tracing dan & Ada \\
\hline
\end{tabular}

\begin{tabular}{|c|c|c|}
\hline \multicolumn{3}{|c|}{ Treatment) } \\
\hline $\mathrm{N} 4$ & Work From Home (WFH) & Ada \\
\hline N5 & Rapid Test - Acak & $\begin{array}{l}\text { Tidak } \\
\text { Ada }\end{array}$ \\
\hline N6 & Rapid Test - Tinggi Risiko & Ada \\
\hline N7 & Rapid Test - Semua & Ada \\
\hline N8 & PCR Test & Ada \\
\hline N9 & Cek Temperatur & Ada \\
\hline N10 & Penilaian Risiko Individu & Ada \\
\hline N11 & Dokter/Klinik Dokter & Ada \\
\hline $\mathrm{N} 12$ & Sistem Roasting & Ada \\
\hline N13 & Komunikasi Internal & Ada \\
\hline N14 & Edukasi & Ada \\
\hline N15 & $\begin{array}{c}\text { Pemantauan Pegawai dan } \\
\text { Penegakan }\end{array}$ & $\begin{array}{l}\text { Tidak } \\
\text { Ada }\end{array}$ \\
\hline N16 & $\begin{array}{c}\text { Manajemen Kembali } \\
\text { Bekerja }\end{array}$ & $\begin{array}{l}\text { Tidak } \\
\text { Ada }\end{array}$ \\
\hline N17 & Pemberian Suplemen & Ada \\
\hline
\end{tabular}

\section{PEMBAHASAN}

Pada Ringkasan tindakan pencegahan COVID-19, dapat disimpulkan bahwa rapid test secara acak, Pemantauan Pegawai serta Manajemen kembali bekerja tidak terdapat dalam sistem penanggulangan COVID-19 PT X. Apabila kita merujuk Peraturan Kementerian Kesehatan HK.01.07/MENKES/328/2020 hal tersebut tidak disebutkan secara jelas tentang peraturan detailnya.

Rapid Test hanya dilakukan ketika melakukan contact-tracing apabila ditemukan kasus positif di tempat kerja. Penggunaan Rapid Test secara acak sesuai dengan penelitian (Hafeez, (2020) untuk praktik kerja yang aman, lindungi pekerja dari kontak dekat dengan orang yang terinfeksi dengan menggunakan teknik tambahan dan kontrol administratif seperti pengecekan secara acak. Sedangkan menurut (Plantes, 2021) beberapa negara 
menerapkan strategi pengujian dan pengawasan secara acak yang terbukti efektif dalam mengurangi penularan antarwarga dan berkontribusi dalam menekan COVID-19.

Pemantauan Pegawai juga tidak disebutkan, hal ini sesuai dengan Menteri Kesehatan Republik Indonesia Nomor Hk.01.07/Menkes/328/2020 Tentang Panduan Pencegahan Dan Pengendalian Coronavirus Disease 2019 (COVID-19) Di Tempat Kerja Perkantoran Dan Industri Dalam Mendukung Keberlangsungan Usaha Pada Situasi Pandemi, Pemantauan hanya dilakukan bersifat apabila ada gejala penyakit timbul bukan mengenai Pemantauan Ketegasan Protokol COVID19 di Tempat Kerja.

Manajemen kembali bekerja juga tidak disebutkan didalam peraturan tersebut, namun menurut penelitian (Plantes, 2021) tempat kerja mulai merumuskan strategi "kembali bekerja" yang dirancang untuk mengurangi risiko penularan di antara karyawan. Penelitian tersebut menjelaskan pendekatan yang dapat digunakan oleh perusahaan multisite untuk membantu mengurangi penularan COVID-19 di tempat kerja.

Untuk Faktor Penghalang dan Tantangan, menjaga kepatuhan protocol kesehatan selama bekerja dapat dirujuk ke dalam peraturan Keputusan Menteri Kesehatan Republik Indonesia Nomor Hk.01.07/Menkes/328/2020 Tentang Panduan Pencegahan Dan Pengendalian Coronavirus Disease 2019 (COVID-19) Di Tempat Kerja Perkantoran Dan Industri Dalam Mendukung Keberlangsungan Usaha Pada Situasi Pandemi, Pemantauan hanya dilakukan bersifat apabila ada gejala penyakit timbul bukan mengenai Pemantauan Ketegasan Protokol COVID19 di Tempat Kerja. Kegiatan tersebut dilakukan oleh Petugas kesehatan/petugas K3/bagian kepegawaian di dalam perusahaan. Sedangkan menurut Peraturan Pemerintah Provinsi DKI Jakarta No. 41 Tahun 2020, diterapkan sanksi bagi pelanggar sanksi administratif dalam bentuk peringatan tertulis dan denda administrasi minimal $\mathrm{Rp} 25$ juta dan maksimal Rp50 juta. Pelaksanaan Pencegahan COVID-19 di tempat Kerja perlu diterapkan sanksi dan petugas yang mengontrol kepatuhan Protokol COVID di tempat kerja. (Han, 2020). Kemudian untuk potensi risiko infeksi pada daerah base lokasi, dapat dilihat dengan Gambaran penerapan protokol COVID-19 saat ini hanya ada di Jakarta. Gambaran penerapan protokol COVID-19 saat ini bahwa usia $>60$ tahun lebih patuh terhadap perilaku penerapan protokol kesehatan dan berdasarkan jenis kelamin, responden perempuan jauh lebih patuh dalam perilaku penerapan protokol kesehatan (Hanoatubun, 2020). Sumber daya yang tidak mencukupi dihadapkan pada Pandemi COVID-19 saat ini telah mengganggu industri penerbangan dengan ketidakpastian kapasitas yang berkurang, permintaan yang lemah, dan pengembalian yang tidak pasti ke tingkat pra-2020 (Sobieralski, 2020). Sebagai gambaran, Indonesia mencatat 2.703 penerbangan di 15 bandara dibatalkan sepanjang Januari-Maret 2020. Rinciannya yaitu 11.680 untuk penerbangan domestik dan 1.023 untuk penerbangan internasional dengan Rinciannya yaitu 11.680 untuk penerbangan domestik dan 1.023 untuk penerbangan internasional. Angka kehilangan pendapatan di sektor layanan udara mencapai Rp 207 miliar (Hanoatubun, 2020). Selanjutnya, untuk persyaratan penerbangan yang membuat bingung penerbang Hal ini selaras dengan penelitian (Cook, 2020) tentang beberapa pelaku industri mengalami kebingungan dalam memperbaharui protokol COVID-19 di tempat kerja.

Faktor pendorong seperti mencegah dan melindungi karyawan sesuai dengan undang-undang keselamatan kerja serta Peraturan Kementerian Kesehatan HK.01.07/MENKES/328/2020, bahwa Perusahaan wajib melindungi pekerja dalam bekerja terutama saat pandemi COVID-19 berlangsung. 
Dapak yang dihasilkan seperti rendahnya permintaan akan kebutuhan industry penerbangan sesuai dengan IATA (International Air Transport Association) dalam memprediksi Coronavirus memiliki potensi untuk secara fundamental mengganggu pertumbuhan kapasitas maskapai penerbangan global tahun 2020 . Wabah virus juga akan berdampak pada profitabilitas maskapai. Hal tersebut merugikan maskapai dalam jumlah besar dengan biaya tambahan dan menghilangkan segmen lain dari industri perjalanan, termasuk hotel dan wisatawan (Mhalla,2020). Perubahan lingkungan kerja menjadi daring juga didapat oleh penelitian (Cook, 2020) bahwa penerapan protokol COVID-19 mengharuskan memanfaatkan teknologi baru agar dapat beradaptasi dengan kegiatan seluruh operasi. Serta adanya tambahan biaya (additional cost) untuk test COVID-19 Sesuai dengan (Cook, 2020), Kebutuhan akan pelaksanaan tes COVID-19 tidaklah sedikit dan terbatas, sehingga perusahaan disarankan skema tambahan untuk menyediakan dana, dan/atau sumber daya lain untuk membantu organisasi.

\section{KESIMPULAN}

Implementasi protokol kesehatan COVID-19 pada PT X secara umum sudah baik. PT X mengalami dampak yang cukup signifikan di operasional seperti pada umumnya perusahaan penerbangan lainnya. Beberapa faktor-faktor signifikan yang berpengaruh dalam implementasi Protokol COVID-19 di PT X, yaitu : Faktor Penghalang dan Tantangan seperti menjaga protokol kesehatan di daerah lokasi kerja, Potensi risiko di daerah yang terbesar, sumber daya yang terbatas, terbatasnya operasionalnya penerbangan, kemudian Faktor Pendorong seperti adanya komitmen keselamatan dan kesehatan kerja serta keberlangsungan bisnis. Untuk Dampak yang dihasilkan, seperti rendahnya permintaan akan kebutuhan industri penerbangan, adaya perubahan lingkungan kerja secara daring serta adanya tambahan biaya (additional cost) untuk tes COVID19 didalam operasional penerbangan.

\section{UCAPAN TERIMAKASIH}

Penulis mengucapkan terima kasih sebesar-besarnya kepada PT X, Pembimbing Akademik Universitas Indonesia Ibu Dr. Robiana Modjo, SKM, M.Kes, teman-teman Magister K3 FKM UI 2019 serta beberapa pihak lainya yang saya tidak bisa sebut satu persatu.

\section{DAFTAR PUSTAKA}

Nuhelicopters.com (2020, 14 Februari). Company Profile PT X. Diakses pada tanggal 25 Februari 2021 dari http://www.nuhelicopters.com/

Cook, M., Lestari, F (2020). Implementation of the Corona Virus (COVID-19) Disease Prevention and Control Guide 2019 in the Office and Industrial Workplaces' within selected industries in Indonesia. The Australia-Indonesia Centre.

COVID-19.kemenkes.go.id (2020, 24 Februari). Situasi Terkini Perkembangan Novel Coronavirus (COVID-19). Diakses pada tanggal 25 Februari 2021 dari https://covid19.kemkes.go.id/dow nload/Situasi_Terkini_021220.pdf

Dekker, B. (2020). Impact of COVID-19 measures on Indonesian value chains. Clingendael Institute.

Hafeez, A., Ahmad, S., Siddqui, S. A., Ahmad, M., \& Mishra, S. (2020). A review of COVID-19 (Coronavirus Disease-2019) diagnosis, treatments and prevention. EJMO, 4(2), 116-125.

Hall, M. T., Bui, H. Q., Rowe, J., \& Do, T. A. (2020). COVID-19 Case and Contact Investigation in an Office Workspace. Military Medicine, 185(11-12), e2162-e2165.

Hanoatubun, S. (2020). Dampak Covid-19 terhadap Prekonomian Indonesia. 
EduPsyCouns: Journal of Education, Psychology and Counseling, 2(1), 146-153.

Bureau, A. T. (2020). Effects of Novel Coronavirus (COVID-19) on Civil Aviation: Economic Impact Analysis. International Civil Aviation Organization (ICAO), Montréal, Canada.

Mhalla, M. (2020). The impact of novel coronavirus (COVID-19) on the global oil and aviation markets. Journal of Asian Scientific Research, 10(2), 96.

Plantes, P. J., Fragala, M. S., Clarke, C., Goldberg, Z. N., Radcliff, J., \& Goldberg, S. E. (2021). Model for mitigation of workplace transmission of COVID-19 through population-based testing and surveillance. Population Health Management, 24(S1), S-16.

Sarsby, A. (2016). SWOT analysis. Lulu. com.

Sobieralski, J. B. (2020). COVID-19 and airline employment: Insights from historical uncertainty shocks to the industry. Transportation Research Interdisciplinary Perspectives, 5, 100123.

Walker, Diane (2006) Grounded Theory: An Exploration of Process and Procedure, QUALITATIVE HEALTH RESEARCH, Vol. 16 No. 4, April 2006 547-559.

WHO (2020) Coronavirus disease 2019 (COVID-19) Situation Report - 94 23 April 2020, page 1-2. 